\title{
Insecurity, Identity Politics, and the Restructuring of the Middle East
}

\author{
Raffaella A. Del Sarto, SAIS Europe, The Johns Hopkins University School of Advanced International Studies
}

Identity politics are not a new phenomenon in the Middle East; they have witnessed several ebbs and flows (Telhami and Barnett 2002). The current era is characterized by a distinctive level and intensity of identity politics, however, which must be seen as an integral part of the emergent structure of regional politics. This essay advances three main claims about the current "flow" of identity politics in the region. First, the rise of ethno-religious politics cannot be explained in terms of the specificities of Arab politics because the trend is not limited to Muslim majority countries. Israel offers a prominent but generally overlooked example. Second, the sharpening of ethnoreligious difference is the result of strategic action under specific enabling conditions. The sense of insecurity and fear in periods of transition is a crucial enabling condition. Ironically, however, a heightened sense of insecurity not only acts as an enabling condition but is also the outcome of the politics of fear adopted by political leaders in the region. Third, the rise of identity politics is a trend on a broader scale, as seen in the United States and Europe. The memo concludes by reflecting on the role of local actors and developments as well as on the implications of the growing power of ethno-religious politics in the Middle East-and beyond. 1

\section{Beyond Muslim sectarianism: Identity politics in Israel}

Discussion of Identity politics in the current Middle East often focuses exclusively on sectarianism or on the role of political Islam (e.g. POMEPS 2013). But what type of identity politics are we referring to? By invoking universalist values and ideas, identity politics may be inclusive. But if politics are framed on the basis of belonging to allegedly primordial ethnic or religious groups, as is the case in the Middle East at present, an exclusionary and antagonistic type of identity politics is at work. In parallel, we have been witnessing the securitization of religious and ethnic identities in the region, that is, the invoking or construction of communities as being under threat (Malmvig 2015: 32; 2014). These collective identities, which are or have become real, are moved to the realm of "panic politics" (Buzan et al. 1998: 34), thereby legitimizing exceptional means. Sectarian identities have turned into sources of conflict (Darwich and Fakhoury 2017), fomenting fragmentation within and among states. Current identity politics in the region thus differ from those in the past, most notably pan-Arabism with its unifying rhetoric at the supranational level (no matter the divisions it caused among states in practice) (Kerr 1971; Valbjørn and Bank 2012).

While it is fashionable to invoke the age-old Sunni-Shi'a divide as the explanation for the current violence in the region, ethno-religious politics have also been on the rise in Israel.

Ethno- religious conceptions of state- and nationhood were built into the Israeli state from the outset, as Zionism's objective of creating a "state of the Jews" indicates. In recent decades, identity politics in Israel have clearly been on the rise (Del Sarto 2017a). This development is reflected in the ever-growing power of the neo-revisionist Israeli Right, which in turn manifests in important changes in both domestic Israeli politics and in its foreign policy.

The recent adoption of the "Jewish nation-state law," which anchors the definition of Israel as the Jewish nation-state in the country's basic laws (Israel's version of a constitution), is perhaps the most obvious case in point. The law reserves the right to self-determination to the Jewish collective only, relegating the Palestinian-Arab minority which constitutes

\footnotetext{
${ }^{1}$ The author would like to thank Maria-Louise Clausen, May Darwich, Waleed Hazbun, Amaney Jamal, Kristina Kausch, Mark Lynch, Karim Makdisi and Morten Valbjørn for great comments on a previous draft of this memo.
} 
about $20 \%$ of Israeli citizens to a secondary status outside the collective. Numerous opinion polls confirm the strong domestic support for ethno-religious conceptions of stateand nationhood. For example, a growing number of Jewish Israelis think that a "Jewish state" is more important than a democratic one (Hermann et al. 2014). In 2016, 52\% of Jewish Israelis believed that Israeli citizens who are unwilling to declare that Israel is the nation-state of the Jewish people should be stripped off their voting rights. A staggering $59 \%$ of Jewish Israeli respondents oppose the participation of Arab parties in governments (Hermann et al. 2016). According to another poll, 48\% of Jewish Israeli respondents regarded the Palestinians' recognition of Israel as the state of the Jewish people as more important than reaching a peace agreement with them (Israel Democracy Institute 2016).

Dominant perceptions of existential threats emanating from the outside world shape this emergent power of ethno-religious ideas in Israel. The prevailing view is that the country is facing existential threats, with the ultimate objective of its enemies being the destruction of the "Jewish state." While these notions are not new (Maoz 2009), the securitization of Jewish identity increased after the outbreak of the second Palestinian Intifada in 2000. With terrorism becoming a major concern, Israeli political leaders claimed that "there is no partner for peace" on the Palestinian side. They also referred to the inherently evil nature of Iran and its proxies, including Hizballah and Hamas, while warning of a possible "second Holocaust" (Klein Halevi and Oren 2007). These ideas convey a strong sense of besiegement and tend to define the regional reality as a struggle between the Arab/Muslim world (or large parts of it) and the Jewish people.

The domestic support for these positions, and the policies they prescribe, has been striking. For example, a vast majority of Jewish Israelis came to believe that the Palestinians are not interested in peace (Halperin and Bar-Tal 2007; Israel Democracy Institute 2018). Between $80 \%$ and $94 \%$ of Jewish Israelis supported Israel's three wars on the Hamas-ruled Gaza Strip (Ben Meir 2009; Israel Democracy Institute 2014) - an extremely high percentage considering the high number of Palestinian fatalities. A vast majority of Jewish Israelis is, and remains, afraid of Iran obtaining nuclear weapons (Israel Democracy Institute 2017). Accordingly, the domestic support for Netanyahu's preferred option of bombing Iranian nuclear sites was large (Center for Iranian Studies 2009)_and probably still is.

Of course there is a material basis to at least some of these threat perceptions: terrorist attacks and saberrattling neighbors are real. However, while fears can be manipulated, they contradict the notable improvement of Israel's security environment post-Arab uprisings: Israel is certainly concerned with the presence of Hizballah and Iranian forces in neighboring Syrian territory, but Assad's Syria is no longer a threat and Hizballah is bogged down in Syria for now. Furthermore, Egypt's al-Sisi shares Israel's hostility towards Hamas and Israel's ties to Saudi Arabia and a number of smaller Gulf monarchies have improved, based on their common dislike of Iran. And Israel's hawkish policies have the full support of US President Trump.

\section{Strategic action and the politics of fear}

These developments in Israeli identity politics can be explained in terms of the same theories which account for the rise of sectarianism and other identities in the rest of the Middle East. Political elites may construct ethno-religious antagonism in order to acquire or maintain power (Fearon and Laitin 2000). Corroborating that group leadership (and thus agency) is crucial, the literature also stresses that specific socio-economic and political circumstances enable "successful" identity politics. In this context, studies highlight the important role played by collective threats in breeding ethnocentric and authoritarian attitudes and behavior (e.g. Fritsche et al. 2011). The important point is that insecurity and fear-whether genuine or generated-are not only key enabling conditions that breed the rise of ethnocentric politics (Fritsche et al. 2011). They are also the outcome of strategic action, namely the politics of insecurity and the securitization of collective identities in which political leaders engage. In other words, leaders in the Middle East 
may feel threatened and insecure, but they also have every reason to cultivate a deep sense of insecurity: it increases the legitimacy and domestic support of the exceptional politics they adopt, for the sake of "security." Hence, the "politics of fear" often trigger a peculiar vicious circle.

In the case of Israel, the central role of Jewish history in the construction of Israeli identity acts as a predisposition for the current rise of ethno-religious politics. In other words, a deep sense of insecurity was built into the Jewish-Israeli collective experience from the outset, which the ongoing conflict with the neighbors only reinforced (Zerubavel 1995; Kimmerling 2001). The growing power of ethnoreligious conceptions can also be linked to demographic shifts that have widened the basis of right-wing voting behavior over the decades.? More recently, the violence of the second Intifada and the collapse of Oslo were crucial: They contributed to a general sense of insecurity and fear, prompting most Israeli voters to cast their ballot for the political Right (Berrebi and Klor 2008).

Agency matters, too. Then-Prime Minister Barak deserves the credit for coining the "no Palestinian partner for peace" slogan after the failed Camp David summit in 2000 (Halperin and Bar-Tal 2007). In addition, the Israeli army and the media promoted one-sided representations of reality (Dor 2004). But perhaps most importantly, amid rising sentiments of insecurity during the Intifada, Israel's right-wing governments have promoted identitybased conceptions of threats. They have highlighted the danger of terrorism targeting the Israeli Jewish collective, repeated the claim that there was no one to talk to on the Palestinian side, and insisted that Iran was an existential threat (see Del Sarto 2017a for details). Israeli governments have thus engaged in the politics of insecurity and fear. As the conflict with the Palestinians became redefined as an exclusively ethnic struggle (Klein 2010), political debates have been replaced by a general acceptance of a hardline approach to security.
A look at the broader Middle East confirms that the interaction between structural change and agency is a crucial factor in the rise of ethno-religious politics in periods of uncertainty. For example, the collapse of the Ottoman Empire and the struggle against Western colonialism created an "identity vacuum" which "fuelled the rise of Arab nationalism" (Hinnebusch 2013: 150). Arab leaders were quick in using Pan-Arabism in their quest for regional hegemony (Kerr 1971). Similarly, the rise of political Islam from the 1970s onwards occurred in a period of profound uncertainty, caused by the 1967 defeat of Arab armies against Israel (Al-Azm 2012) and the decline of Pan-Arabism. Similarly, the rise of Shi'a identity from the mid-1970s onwards took place in a period of uncertainty, with a new generation of politicized Shi'a religious leaders - and the new regime in Iran after the 1979 revolution - exploiting identity for political ends.

The US invasion of Iraq in 2003 triggered an unprecedented wave of ethno-religious polarization from the mid-2000s onwards. With Iran becoming more assertive after the defeat of archenemy Saddam Hussein, the US intervention prompted a growing antagonism between Sunnis and Shi'a. The sectarian politics of then Iraqi Prime Minister Al-Maliki's would only deteriorate the situation. This case once more exemplifies the significant role of self-interested actors in accentuating and exploiting ethno-religious difference in situations of pronounced instability. Finally, in the extremely volatile period postArab uprisings, with Arab regimes being concerned with their survival (Ryan 2015), regional powers have been accentuating sectarian differences in their quest for regional hegemony (Valbjørn and Bank 2010; Lynch 2016).

\section{Beyond the Middle East}

Exclusionary identity politics do not seem to be a Middle Eastern prerogative. In the US and Europe, right-wing populist movements are gaining support, with tribalism, victimhood and xenophobia being on the rise (e.g.

\footnotetext{
${ }^{2}$ These include the shift toward a majority of Mizrahi Jewish voters since the 1970s, the steady growth of Israel's Jewish religious population (higher birth rates) and the immigration from the former Soviet Union in the 1990s.
} 
Fukuyama 2018). But in the absence of comparable levels of conflict, what explains the rise of identity politics in "the West"? While I do not have a definite answer, and with every case having its specificities, two suggestions can be made. But we should first recall that security, or the lack thereof, is a subjective sentiment. While there is clearly a difference between living in a Syrian war zone, or, say, in Switzerland, threats or perceived threats-to survival, security, or economic status-seem to be equally significant.

Against the background of globalization and the spread of neoliberalism, the 2008 financial crisis bred a lasting sense of insecurity in many Western societies. It entailed cuts to real wages, rising inequality and poverty, a shrinking welfare state, and the erosion of the economic status of the middle class. In many states, politicians-of all stripes-have not addressed these issues, leaving the playing field to populist forces. The appeal of identity politics may thus be a consequence of this development. Yet ironically, identity politics also contribute to the spread of unchecked neo-liberal economics and their inherent inequality (Fraser 2017; Richardt 2018): while diverting the attention from crucial political questions, they atomize societies into different "tribes" that could otherwise join forces to address pressing economic and political issues. Economic insecurity is also widespread in the Middle East. In many Arab states, the expansion of neo-liberalism forged the emergence of a class of nouveau riches linked to political power (Guazzone and Pioppi 2012), along with rising inequality. And Israel and Turkey are among the eight OECD countries with the highest income inequality (OECD 2018).

Secondly, the role of social media seems to be relevant. Acting as so-called echo-chambers among like-minded users, social media have been accused of spreading racism, misogyny and tribalism. $\underline{3}$ People also seem to react stronger to negative messages, with posts that trigger fear having the highest media shares. Right-wing populist forces in the US and in Europe, and their foreign supporters, have aptly manipulated and exploited popular feelings of insecurity, anger, and fear, as evidenced by Russian internet trolls and fake social media accounts during the last US electoral campaign. Social media may thus provide a fertile ground for ethno-religious politics in Western and Middle Eastern societies alike.

\section{Conclusions}

A pronounced sense of insecurity in periods of transition is both an enabling condition for the "successful" manipulation and securitization of ethno-religious identities and the outcome of the politics of fear adopted by aspiring or incumbent leaders. The resulting vicious circle of exclusionary identity politics points to the mutually constitutive nature of structure and agency. Political leaders thus engage in antagonistic identity politics out of fear and/or to legitimize their rule, but their policies-often bolstered by assertive foreign policiesonly increase the sense of insecurity while potentially destabilizing the region further. Moreover, ethno-religious politics prevent the emergence or consolidation of liberal polities that could engage in regional cooperation (Solingen 2007). The conflict potential of the region is thus likely to remain high.

Second, traditional boundaries of state sovereignty are increasingly blurred, as state and non-state actors become connected through powerful identity dynamics (Philipps and Valbjørn 2018). Perhaps ironically, transnational identity alliances may actually undermine the authority of those national leaders. This is significant as many regimes in the region lack domestic legitimacy, which has only worsened post-Arab uprisings (Hudson 2015; Del Sarto 2017b). The securitization of identities also legitimizes the meddling of external actors in the domestic affairs of Middle Eastern states, again to the detriment of national political leaders.

\footnotetext{
${ }^{3}$ See Microsoft's 2016 launching of an AI chat-bot named Tay, which was meant to learn from its interaction on social media. It quickly learned to tweet racist and misogynist comments, to the point that Microsoft decided to end the experiment after only 16 hours (Hayasaki 2016).
} 
Third, external interventions (most notably the US invasion of Iraq and its long-term consequences) and global power shifts contribute to the region's volatility, as does the persistence of violence post-Arab uprisings. However, an exclusive top-down approach to regional developments is insufficient. While global, regional, and domestic dynamics interlock and condition each other (Clausen, Darwich, Hazbun, Ulrichsen), our case points to the crucial role of local actors. The significance of endogenous Middle Eastern actors and factors thus validates the argument made by Snyder (1993) on the domestic source of regional conflict.

Finally, while each case has its specificities, in this case a comparative perspective to the study of Israel and the broader Middle East (Barnett 1996) is extremely useful-in spite of its unpopularity. Furthermore, the rise of identity politics and the decline of liberalism in "the West" (Zielonka 2018) seem to embed the Middle East in peculiar political dynamics that transcend the region. The phenomenon of identity politics thus defies the notion of Middle Eastern exceptionalism, together with a narcissistic "region-centric perspective" (Valbjørn). To conclude, the question of how to put the genie of antagonistic identity politics back into the bottle is of fundamental importance for the future of the Middle East-and far beyond.

\section{References}

Al-Azm, Sadiq (2012). Self-Criticism after the Defeat, London: Saqi.

Barnett, Michael N., ed. (1996). Israel in Comparative Perspective: Challenging the Conventional Wisdom, Albany: SUNY Press.

Ben Meir, Yehuda (2009). “Operation Cast Lead: Political Dimensions and Public Opinion," Strategic Assessment 11(4), Tel Aviv: Institute for National Security Studies, 29-34.

Berrebi, Claude, and Esteban F. Klor (2008). "Are Voters Sensitive to Terrorism? Direct Evidence from the Israeli Electorate," American Political Science Review 102(3): 279301.
Buzan, Barry, Ole Wæver, and Jaap de Wilde (1998). Security: A New Framework for Analysis, Boulder, CO: Lynne Rienner.

Center for Iranian Studies (2009). "Public Opinion Poll: Main Findings," Tel Aviv: Tel Aviv University.

Darwich, May and Tamirace Fakhoury (2016). "Casting the Other as an Existential Threat: The Securitisation of Sectarianism in the International Relations of the Syria Crisis," Global Discourse 6(4): 712-732.

Del Sarto, Raffaella A. (2017a). Israel under Siege: The Politics of Insecurity and the Rise of the Israeli NeoRevisionist Right, Washington, D.C.: Georgetown University Press.

Del Sarto, Raffaella A. (2017b) 'Contentious Borders in the Middle East and North Africa: Context and Concepts', International Affairs 93(4): 787-797.

Dor, Daniel (2004). Intifada Hits the Headlines: How the Israeli Press Misreported the Outbreak of the Second Palestinian Uprising, Bloomington: Indiana University Press.

Fearon, James and David Laitin (2000). "Violence and the Social Construction of Ethnic Identity," International Organization 54(4): 845-877.

Frazer, Nancy (2017). "From Progressive Neoliberalism to Trump-and Beyond," American Affairs 4(1), at https://americanaffairsjournal.org/2017/11/progressiveneoliberalism-trump-beyond/

Fritsche, Immo, Eva Jonas and Thomas Kessler (2011). "Collective Reactions to Threat: Implications for Intergroup Conflict and for Solving Societal Crises," Social Issues and Policy Review 5 (1): 101-136.

Fukuyama, Francis (2018) "Against Identity Politics: The New Tribalism and the Crisis of Democracy," Foreign Affairs, September/October. 
Guazzone, Laura and Daniela Pioppi (eds.) (2012) The Arab State and Neo-Liberal Globalization: The Restructuring of State Power in the Middle East, Reading: Ithaca Press.

Halperin, Eran and Daniel Bar-Tal (2007) "The Fall of the Peace Camp in Israel: The Influence of Prime Minister Ehud Barak on Israeli Public Opinion, July 2000-February 2001," Conflict and Communication online 6(2), at http:// www.cco.regener-online.de/2007_2/pdf/halperin.pdf Hayasaki, Erika (2017) “Is AI Sexist?, Foreign Policy, 16 January, at https://foreignpolicy.com/2017/01/16/womenvs-the-machine/

Hermann, Tamar, et al. (2014). "The Israel Democracy Index 2014: Highlights." Jerusalem: The Israel Democracy Institute, at https://en.idi.org.il/search?q=The\%20Israel\%20 Democracy\%20Index\%202014\%3A\%20Highlights

Hermann, Tamar, et al. (2016): "The Israel Democracy Index 2016: Highlights." Jerusalem: The Israel Democracy Institute, at https://en.idi.org.il/publications/11985

Hinnebusch, Raymond (2013) “The Politics of Identity in Middle East International Relations," in International Relations of the Middle East, edited by Louise Fawcett, third edition, Oxford: Oxford University Press, pp. 148-163.

Hudson, Michael C. (2015) "Arab Politics after the Uprisings: Still Searching for Legitimacy," in Larbi Sadiki, ed., The Routledge Handbook on the Arab Spring, London: Routledge.

Israel Democracy Institute (2014). “The Peace Index: August 2014," at http://peaceindex.org/indexMonthEng. aspx?num $=283$

Israel Democracy Institute (2016). “The Peace Index: April 2016," at http://www.peaceindex.org/indexMonthEng. aspx? num=304\&monthname=April, accessed 13 August 2018.
Israel Democracy Institute (2017). “The Peace Index: November 2017," at http://www.peaceindex.org/ indexMonthEng.aspx?num=327\&monthname=November, accessed 13 August 2018.

Israel Democracy Institute (2018). “The Peace Index: July 2018," at http://www.peaceindex.org/indexMonthEng. aspx?num $=333$

Kerr, Malcolm H. (1971). The Arab Cold War: Gamal 'abd Al-Nasir and His Rivals, 1958-1970, London, New York: Oxford University Press.

Kimmerling, Baruch (2001). The Invention and Decline of Israeliness: State, Society, and the Military, Berkeley: University of California Press.

Klein Halevi, Yossi and Michael B. Oren (2007). “Israel's Worst Nightmare," The New Republic, 30 January.

Klein, Menachem (2010). The Shift: Israel-Palestine from Border Struggle to Ethnic Conflict, New York: Columbia University Press.

Lynch, Marc (2016). The New Arab Wars: Uprising and Anarchy in the Middle East, Washington, DC: PublicAffairs.

Malmvig, Helle (2014). "Power, Identity and Securitization in Middle East: Regional Order after the Arab Uprisings." Mediterranean Politics 19 (1): 145-148.

Malmvig, Helle (2015) "Coming in from the Cold: How We May Take Sectarian Identity Politics Seriously in the Middle East without Playing to the Tunes of Regional Power Elites," Project on Middle East Political Science (POMEPS) Studies no. 16, 17 September, at http://pomeps.org/2015/08/19/ coming-in-from-the-cold-how-we-may-take-sectarianidentity-politics-seriously-in-the-middle-east-withoutplaying-to-the-tunes-of-regional-power-elites/

Maoz, Zeev (2009). Defending the Holy Land: A Critical Analysis of Israel's Security and Foreign Policy, Ann Arbor: University of Michigan Press. 
OECD (2018) Income Inequality (Indicator), doi:

10.1787/459aa7f1-en, accessed 23 September 2018.

Phillips, Christopher and Morten Valbjørn (2018). "What is in a Name?': The Role of (Different) Identities in the Multiple Proxy Wars in Syria," Small Wars E Insurgencies 29(3): 414-434.

POMEPS (2013) The Politics of Sectarianism, Project on Middle East Political Studies (POMEPS) Study no. 4, 13 November, at https://pomeps.org/wp-content/ uploads/2014/06/POMEPS_Studies4_Sectarianism.pdf

Richardt, Johannes (ed.) (2018) Die sortierte Gesellschaft: Zur Kritik der Identitätspolitik, Frankfurt a.M.: Novo Argumente Verlag.

Ryan, Curtis R. (2015) "Regime Security and Shifting Alliances in the Middle East," in International Relations Theory and a Changing Middle East, POMEPS Studies 16, 17 September, pp. 42-46, at http://pomeps.org/2015/09/17/ international-relations-theory-and-a-new-middle-east/

Snyder, Jack (1993) Myths of Empire: Domestic Politics and International Ambition, Ithaca: Cornell University Press.
Solingen, Etel (2007) "Pax Asiatica versus Bella Levantina: The Foundations of War and Peace in East Asia and the Middle East," American Political Science Review 101(3): 757-80.

Telhami, Shibley and Michael Barnett (2002) "Introduction: Identity and Foreign Policy in the Middle East," in Shibley Telhami and Michael Barnett, eds. Identity and Foreign Policy in the Middle East, Ithaca: Cornell University Press, chapter 1 .

Valbjørn, Morten and André Bank (2012) “The New Arab Cold War: Rediscovering the Arab Dimension of Middle East Regional Politics," Review of International Studies, 38(1): 3-24.

Zerubavel, Yael (1995). Recovered Roots: Collective Memory and the Making of Israeli National Tradition, Chicago: University of Chicago Press.

Zielonka, Jan (2018) Counter-Revolution: Liberal Europe in Retreat, Oxford: Oxford University Press. 